\title{
Monitoring of PAHs in the natural protected areas in non-heating season using Norway spruce (Picea abies (L.) Karst) needles
}

\author{
Jacek Borgulat ${ }^{1,{ }^{*}}$, Tomasz Staszewski ${ }^{1}$, Włodzimierz Łukasik \\ ${ }^{1}$ Institute for Ecology of Industrial Areas, Kossutha 6, 40-844 Katowice, Poland
}

\begin{abstract}
This paper presents the results of the screening investigation of the environmental burden of polycyclic aromatic hydrocarbons (PAHs) in the natural protected areas in non-heating season. Current year spruce needles were used as a bioacummulative indicator. The total exposure at 15 PAHs (2-6 rings) and carcinogenic potential of these compounds were taken as parameters describing the hazard level. Sampling, in a uniform way, was made in the Silesian Voivodeship landscape parks and the selected Polish national parks as well as in the reference sites with characteristic pattern of PAHs emission, namely in industrialized urban areas and near the expressway. The presence of PAHs, including carcinogenic ones, was shown in all the localities; their content in needles sampled in the natural protective areas was slightly diversified and ranged from 145 to $339 \mathrm{ng} / \mathrm{g}^{-}$(d. w.). Higher differences were observed for carcinogenic potential index (CP) which varied from 2.2 to 18.2. The analysis of PAHs profiles has shown that despite the seasonal lack of intensive emissions from domestic heating, in the majority of natural protective areas pyrogenic sources have also been identified. Profiles of PAHs found in Karkonoski and Ojcowski NPs suggest their petrogenic origin probably due to the intensive tourism (emissions from car engines) in those areas.
\end{abstract}

Keywords: Polycyclic aromatic hydrocarbons (PAHs), carcinogenic PAHs, Picea abies, biomonitoring, non-heating time

\section{Introduction}

PAHs in ambient air are produced by incomplete combustion of coal, oil, petroleum, wood and plastics. PAHs contain from 2 to 7 rings, while the most toxic of them contain from 4 to 7 rings [1]. The adverse effects of these compounds on human health are connected with metabolic conversion into mutagenic, carcinogenic and teratogenic

\footnotetext{
${ }^{*}$ Corresponding author: j.borgulat $@$ ietu.pl
} 
substances. They easily bond with RNA and DNA and as the result they disrupt the replication processes, which may lead to tumour formation [2]. PAHs with a number of rings $\geq 4$ are absorbed on particulate matter in the atmosphere, while PAHs with fewer rings may persist in a gas phase [3]. PAHs are strongly absorbed by organic matter in soil and are unavailable for plant uptake [4]. Therefore, PAH deposition on leaves is a function of their concentration in the air [5]. Thus leaves are a convenient passive sampler for the monitoring PAH content in the air. Particularly the coniferous, including spruce, are good a candidate for PAHs bioindicator due to all-year exposure to air pollutants and chemical structure of needles; their cuticle possesses strong lipophilic properties affecting the accumulation of airborne PAHs [6-9]. The waxy surface of needles not only traps particulates but it can also intercept vapor phase contaminants [10]. The amount and sorption properties of cuticle also depends on age and time of year (mainly due to ambient temperature) [11].

The content of PAHs in assimilatory organs increases together with the time of exposure [12,13]. The leaves collected in winter contain higher amount of PAHs when compared to the ones sampled in spring - summer time. On one hand it is due to a greater deposition of these contaminants on leaf surface resulting from a higher emissions of several pollutants in winter, mainly due to domestic heating [14] and on the other hand due to cumulative properties of leaves surface. Commonly the investigation of PAHs deposit is made using the one- and second-year needles collected in summer and winter time and the PAHs ratios have been used by many authors [18-21] to identify sources of PAHs.

Monitoring benzo[a]pyrene $(\mathrm{BaP})$ concentration in the air, which has been carried out in Poland in 98 stations in towns across the country, showed that the permissible level of this compound

$\left(1 \mathrm{ng} / \mathrm{m}^{3}\right)$ [15] was exceeded in 92 sites. It was also found that concentration of $\mathrm{BaP}$ in the air was several times higher in autumn - winter time when compared to the non-heating time [16]. For example in Katowice at annual concentration amounting to $5.1 \mathrm{ng} / \mathrm{m}^{3}$, the seasonal values were $8.3 \mathrm{ng} / \mathrm{m}^{3}$ and $1.1 \mathrm{ng} / \mathrm{m}^{3}$, respectively [17].

The primary objective of this study was to assess levels of PAH deposited on the current year spruce needles in non-heating time in the remote areas of national and landscape parks and compare them to the amount and profile of PAHs in needles from town areas and from the vicinity of the expressway. Moreover, the attempt was made to identify sources of PAHs and to determine their carcinogenic potential.

\section{Materials and methods}

\subsection{Sampling sites characterisation}

Sampling sites are presented in Figure 1. Sampling was conducted in September with new growth spruce needles taken from six trees and the averaged samples were analysed. In the protected areas the samples were taken in the middle of the forest. In urban locations, the samples were taken about $2 \mathrm{~km}$ from the town centre and about 50 meters from the expressway running through the rural area. 


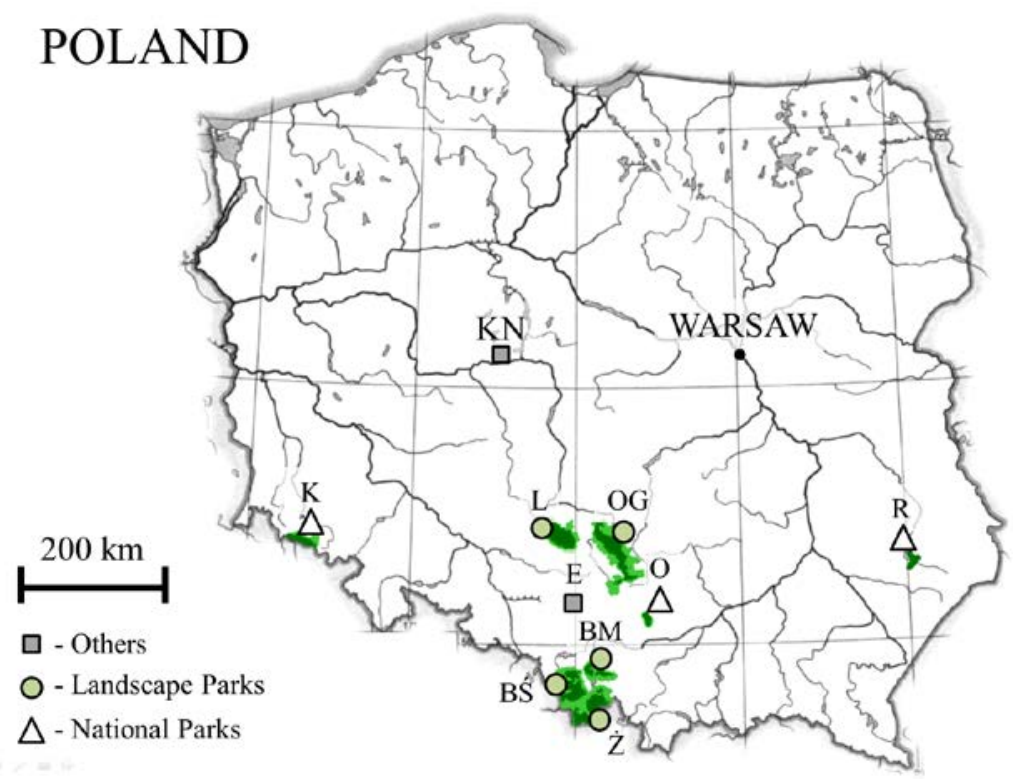

Fig. 1. Location of the study sites (abbreviations: $\mathrm{K}-$ Karkonoski NP, O - Ojcowski NP, RZ Roztoczański NP, BM - Beskid Mały LP, BŚ - Beskid Śląski LP, OG - Orlich Gniazd LP, Ż Żywiecki LP, L - Lasy nad Górną Liswartą LP, KN - Konin, E - Expresway).

The amount of PAH accumulation in needles was recalculated on the basis of dry needle weight [ng/g d. w.]. Characterisation was based on 2 parameters: the total amount of PAHs deposition within needles and carcinogenic potential (CP) of the PAHs deposit. Index CP was introduced with the following formula, on the basis of Table 1:

$C P=\left[\sum\right.$ (amount of carcinogenic $P A H \times \%$ its carcinogenic properties vs $\left.\left.B a P\right)\right] \cdot 100^{-1}$

Table 1. Characteristics of carcinogenic PAHs

\begin{tabular}{|c|c|}
\hline $\begin{array}{c}\text { Compound } \\
\text { (abbreviation, number of rings) }\end{array}$ & $\begin{array}{c}\text { Carcinogenic hazard vs BaP [\%], } \\
\text { EPA Tasmania (2012) }\end{array}$ \\
\hline Benzo[a]antracene (BaA, 4) & 10 \\
\hline Chrysene $(\mathrm{Chr}, 4)$ & 1 \\
\hline Dibenzo[ah]anthracene (DahA, 5) & 109.09 \\
\hline Benzo[b]fluoranthene (BpF, 5) & 10 \\
\hline Benzo[k]fluoranthene (BkF, 5) & 10 \\
\hline Benzo[a]pyrene (BaP, 5) & 100 \\
\hline Indeno[123-cd]pyrene (IcdP, 6) & 10 \\
\hline
\end{tabular}

\subsection{Chemical analysis}

$10 \mathrm{~g}$ of needles from each sample was dried at $30^{\circ} \mathrm{C}$ and grounded for the analysis. Organic compounds were extracted from the plant material using dichloromethane. PAHs were separated on florosil and analysed by HPLC (Hewlett Packard HPLC 1050) using a UV (naphtalene, acenaphthene) and fluorescence detector (the rest of PAHs). Identification of the separated compounds was carried out by the comparison of their retention times with 
the values obtained from a mixture of the Supelco PAH - Mixture $610-$ M [4]. All chemicals used were of analytical great.

The following polycyclic aromatic hydrocarbons (PAHs) listed by the United States Environmental Protection Agency (USEPA) and the European Community as priority pollutants were analysed: naphthalene (Naph), acenaphthene (Ace), fluorene (Fluo), phenanthrene (Phen), anthracene (Ant), fluoranthene (Flt), pyrene (Pyr), benzo[ah]anthracene $(\mathrm{BaA})$, chrysene (Chry), benzo[b]fluoranthene $(\mathrm{BbF})$, benzo[k]fluoranthene $(\mathrm{BkF})$, benzo[a]pyrene $(\mathrm{BaP})$, dibenzo[ah]anthracene (DahA), benzo[ghi]perylene (BghiP), indeno[123-cd]pyrene (IcdP).

Detections limits [ng/g] were as follows: Naph (1.06), Ace (0.76), Fluo (0.76), Phen (2.67), Ant (0.28), Flt (2.76), Pyr (2.14), BaA (0.18), Chry (2.83), BbF (0.13), BkF (0.11), $\mathrm{BaP}(0.18)$, DahA (0.11), BghiP (0.31), IcdP (0.1). The limit of quantification (LOQ) were from $2(\mathrm{BkF})$ to 7 (Flt) ng/g. Recovery results varied between 81 and $96 \%$.

\subsection{Statistical analysis}

A dendrogram was used to determine the similarity in the content of the selected PAHs. Before the analysis was performed, data had been standardized. Dendrogram (distance measure - Euclidean distance, agglomeration method - single bond) was made by STATISTICA (StatSoft, lnc. 2017, ver.13).

\section{Results and Discussion}

The results for PAH biomonitoring using current year spruce needles are presented in Tab. 1. In general, as it was expected, the sites located in urban environment (Konin site) and near expressway had higher contamination levels when compared to the remote sites. The maximum concentration of 15 PAHs was found in Konin followed by the expressway (1097 and $687 \mathrm{ng} / \mathrm{g}$ (d. w.), respectively). In the national and landscape parks, the total concentration of 15 PAHs in needles ranged from $145 \mathrm{ng} / \mathrm{g}$ (d. w.) to $339 \mathrm{ng} / \mathrm{g}$ (d. w.) In all sites, with the exception of the Orlich Gniazd LP and Konin where 4 ring PAHs dominated, 2 and 3 rings compound prevailed making above $60 \%$ of the total PAHs (Tab. 1, 2, Fig. 2.). Konin and Orlich Gniazd LP also showed higher content of 5- and 6- rings PAHs than the others. Higher proportions of low molecular weight PAHs (LPAHs - 2 and 3 rings) especially Naph in the needles were due to their vapor phase which enables their transportation at wide distances [22]. There are large differences in the percentage of PAHs in the examined areas (Tab. 2). The highest variability of all the analyzed classes was found for 6-ring hydrocarbons ( $92 \%$ relative standard deviation). In the investigated sites all 15 PAHs were detected with the exception of DahA in some sites. Naph, Phen,Flt, Pyr, and Fluo were the most concentrated pollutants. These findings point towards the predominantly traffic-related sources for the semi-volatile PAHs [20, 22, 23]. 
Table 1. Content of PAHs [ng/g (d. w.)] in spruce (Picea abies (L.) Karst) needles.

\begin{tabular}{|c|c|c|c|c|c|c|c|c|c|c|}
\hline PAHs & 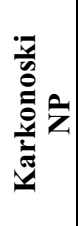 & $\begin{array}{l}\frac{y}{0} \\
\frac{0}{0} \\
\stackrel{0}{0}\end{array}$ & 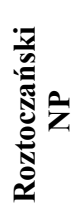 & $\frac{\frac{2}{\pi}}{\sum^{\frac{\pi}{n}}}$ & 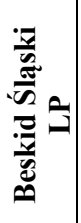 & 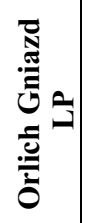 & 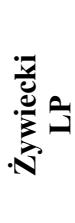 & 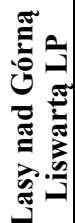 & 沾 & 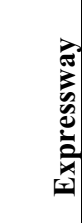 \\
\hline Naph & 86 & 92 & 120 & 33 & 104 & 45 & 92 & 21 & 213 & 148 \\
\hline Ace & 15 & 4 & 2 & 12 & 4 & 11 & 5 & 2 & 2 & 29 \\
\hline Fluo & 16 & 14 & 12 & 25 & 14 & 28 & 5 & 5 & 67 & 41 \\
\hline Phen & 62 & 60 & 12 & 59 & 47 & 31 & 34 & 57 & 99 & 154 \\
\hline Ant & 2 & 3 & 4 & 7 & 7 & 19 & 6 & 6 & 6 & 5 \\
\hline Flt & 70 & 57 & 39 & 31 & 28 & 63 & 23 & 24 & 178 & 114 \\
\hline Pyr & 70 & 58 & 11 & 13 & 13 & 33 & 6 & 11 & 119 & 148 \\
\hline $\mathrm{BaA}$ & 4 & 5 & 7 & 4 & 4 & 16 & 3 & 3 & 36 & 7 \\
\hline Chry & 4 & 11 & 8 & 6 & 6 & 18 & 4 & 4 & 99 & 16 \\
\hline $\mathrm{BbF}$ & 3 & 7 & 3 & 8 & 7 & 13 & 3 & 3 & 73 & 9 \\
\hline $\mathrm{BkF}$ & 2 & 3 & 2 & 4 & 3 & 8 & 2 & 2 & 32 & 5 \\
\hline $\mathrm{BaP}$ & 2 & 1 & 2 & 4 & 3 & 11 & 2 & 1 & 52 & 3 \\
\hline DahA & 0.0 & 0.0 & 0.0 & 1 & 0.0 & 2 & 2 & 0.0 & 3 & 6 \\
\hline BghiP & 4 & 2 & 4 & 5 & 6 & 12 & 3 & 3 & 49 & 2 \\
\hline IcdP & 0.2 & 0.1 & 0.1 & 0.1 & 6 & 11 & 0.1 & 4 & 69 & 0.3 \\
\hline$\sum_{2 \text {-ring }}$ & 86 & 92 & 120 & 33 & 104 & 45 & 92 & 21 & 213 & 148 \\
\hline$\sum_{3-\text { ring PAHs }}$ & 95 & 80 & 29 & 102 & 73 & 89 & 49 & 71 & 174 & 224 \\
\hline$\sum$ 4-ring PAHs & 147 & 132 & 64 & 54 & 51 & 130 & 35 & 42 & 432 & 286 \\
\hline$\sum$ 5-ring PAHs & 6 & 11 & 8 & 17 & 13 & 33 & 8 & 5 & 160 & 23 \\
\hline$\sum$ 6-ring PAHs & 4 & 2 & 4 & 5 & 11 & 23 & 3 & 6 & 118 & 3 \\
\hline$\sum \mathrm{PAHs}$ & 339 & 317 & 224 & 211 & 252 & 319 & 187 & 145 & 1097 & 687 \\
\hline $\mathrm{CP}$ & 3.0 & 2.6 & 3.3 & 6.8 & 5.1 & 18.2 & 5.0 & 2.2 & 77.3 & 11.8 \\
\hline
\end{tabular}

The highest value of the CP index calculated on the basis of equation (1) was found for Konin site (77.3). High values of the index were also found for Orlich Gniazd LP and the Expressway - 18.2 and 11.8, respectively. The average value for CP for all other national and landscape parks amounted to 5.8 (Tab. 1). These values are close to the ones found in some plant species growing in remote sites in Poland (peat bogs). In that research noticeable increases in $\mathrm{CP}$ values in autumn and winter months in relation to spring summer time were observed [25].

Table 2. Mean contents of PAHs [ng/g (d. w.)] in spruce needles collected from protected area (SD - standard deviation, RSD - relative standard deviation [\%]).

\begin{tabular}{|r|r|r|r|r|r|}
\hline PAHs & 2- rings & 3-rings & 4- rings & 5- rings & 6- rings \\
\hline Mean & 70 & 71 & 77 & 13 & 7 \\
\hline SD & 36.0 & 23.8 & 45.6 & 8.7 & 6.6 \\
\hline RSD [\%] & 51 & 33 & 59 & 68 & 92 \\
\hline
\end{tabular}




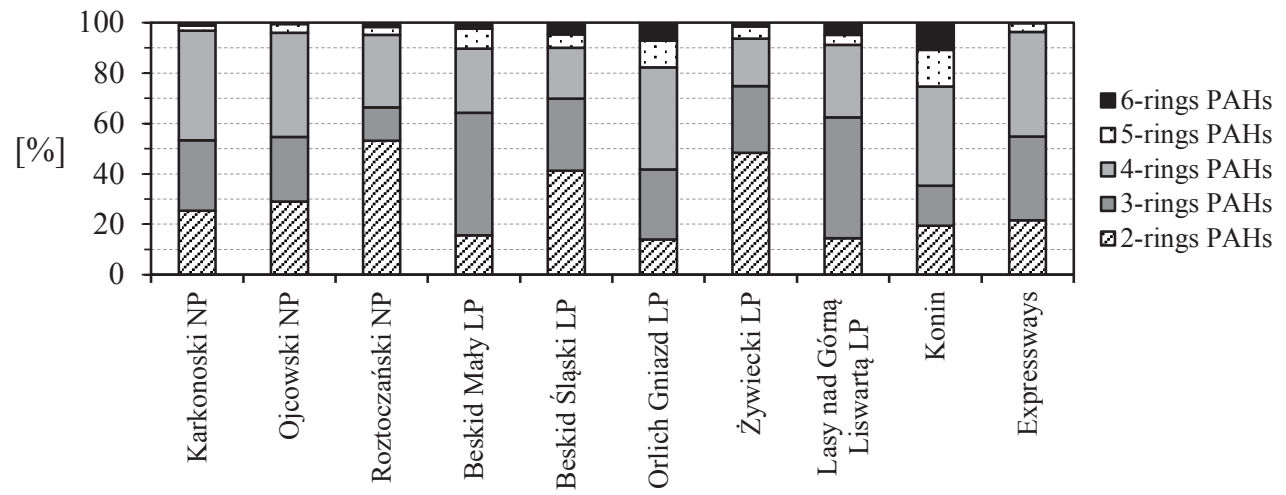

Figure 2. Contribution [\%] of 2-, 3-, 4-, 5- and 6- ring PAHs to total PAH sum in spruce (Picea abies (L.) Karst) needles.

A dendrogram was used to isolate similar areas in terms of 15 measured PAHs. The greatest similarity was found for the two mountain sites - Żywiec LP and Beskid Śląski LP and Karkonoski NP and Ojcowski NP which are close to the Expressway site. The outlying areas are Konin and Orlich Gniazd Landscape Park.

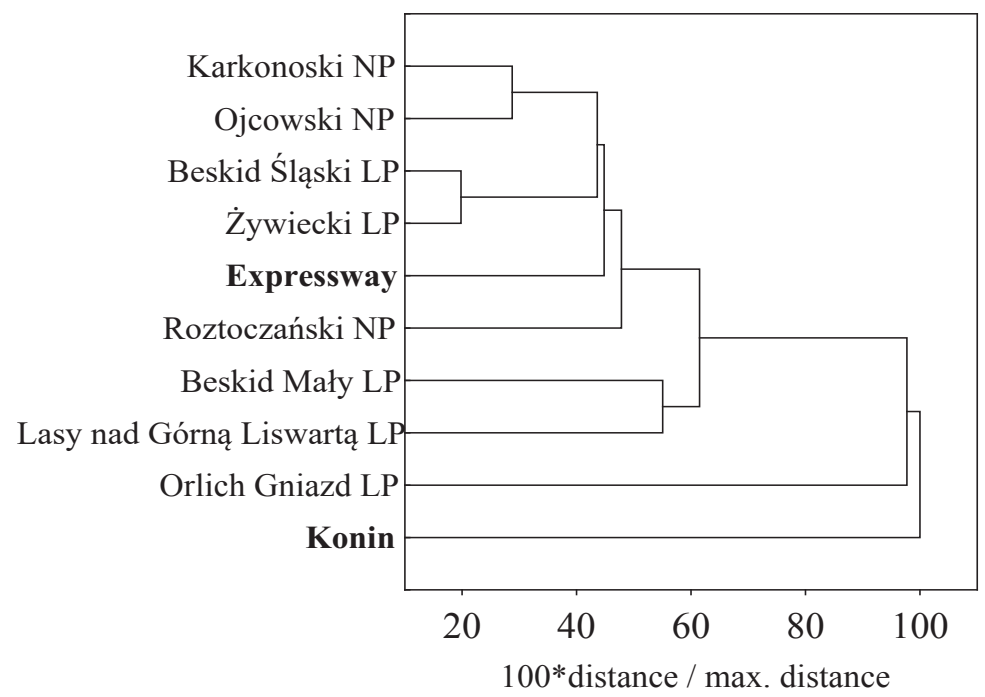

Figure 3. The results of the agglomeration of the examined objects.

In order to determine the presumed origin of PAHs, two diagnostics of PAH distribution ratios were plotted, as presented in Fig. 4. The Fluo/(Fluo + Pyr) ratio was selected for source discrimination because it covers the gaseous as well as the particle transported PAH [26]. These two compounds have comparable physical-chemical properties. It is supposed that variations in the ratio will thus be primarily source associated. Unmodified transfer of source-inherited Fluo/Pyr ratios into different matrices had previously been reported [27]. Ratios between 0.40 and 0.50 are more characteristic of liquid fossil fuel (vehicle and crude oil) combustion, whereas ratios $>0.5$ are characteristic of grass, wood or coal combustion 
[27]. In our research this ratio suggests that in Karkonoski NP, Ojcowski NP and Expressway sites the emissions of PAHs from car traffic are predominant (Fig. 4).

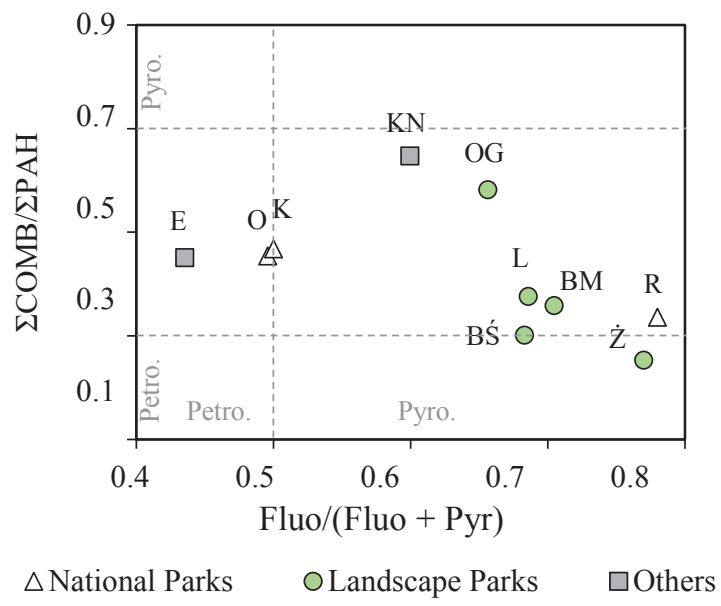

Figure 4. Bivariate plots of $\Sigma \mathrm{COMB} / \Sigma \mathrm{PAH}$ versus Fluo/(Fluo + Pyr) in spruce needles

Another ratio we used was $\Sigma \mathrm{COMB} / \Sigma \mathrm{PAH}$. The $\Sigma \mathrm{COMB}$ is the sum of concentrations of major non-alkylated PAHs'(Fluo, Pyr, BaA, Chr, BbF, BkF, BaP, IcdP and BghiP) and serves as a $\mathrm{PAH}$ indicator of combustion. $\Sigma \mathrm{COMB} / \Sigma \mathrm{PAH}<0.3$ indicates petroleum combustion, when at $\Sigma \mathrm{COMB} / \Sigma \mathrm{PAH}>0.7$ a pyrogenic origin is likely $[19,23]$.

Generally, the needles sampled from our sites were characterized as low $\Sigma \mathrm{COMB} / \Sigma \mathrm{PAH}$ showing the mixed sources of PAHs. Higher $\Sigma \mathrm{COMB} / \Sigma \mathrm{PAH}$ ratio at Konin and Orlich Gniazd LP suggest, that these sites were probably under higher influence of the industrial emissions than the others. Our findings confirm the opinion about the limitations of the use of different ratios of PAHs for its source apportionment which perform well only at sites located near major sources [28].

\subsection{Conclusions}

The use of current year needles exposed for several months in non-heating time to PAHs deposition appears a good tool to assess their inflow and to show a potential hazard due to air pollution, for humans spending time in recreation areas. Carcinogenic potential of PAHs in the air (determined as their deposit on needles) found in the selected natural protected areas in the southern Poland may be regarded as low with the exception of Orlich Gniazd LP. The latter is located in the vicinity of Huta Katowice and industrial works of Olkusz. Nevertheless, the CP index in this site is several times lower than the value found in the industrialized urban area of Konin. Despite the seasonal lack of intensive emissions from domestic heating, PAHs profiles found in the majority of natural protective areas point to the pyrogenic sources. Profiles of PAHs found in Karkonoski and Ojcowski NPs suggest their petrogenic origin probably due to the intensive tourism (emissions from car engines) in those areas. 


\section{References}

1. IARC, Monograph on the Evaluation of the Carcinogenic Risk of Chemicals to Humans. 32 (1983)

2. Thakker, D.R., Yagi, H., Levin, W., Wood, A.W., Conney, A.H., Jerina, D.M., Polycyclic aromatic hydrocarbons: metabolic activation to ultimate carcinogens. In: Bioactivation of Foreign Compounds (New York: Academic Press, 177, 1985)

3. K.C. Jones, G. Sanders, S.R. Wild, V. Burnett, A.E. Johnston, Nature 356, 137 (1992)

4. S.R. Wild, M.L. Berrow, S.P. McGrath, K.C. Jones, Environ. Pollut. 76, 25 (1992)

5. M. Riederer, Environ. Sci. Technol. 24, 829 (1990)

6. Brorström-Lundén, C. Löfgren, Environ. Pollut. 102, 139 (1998)

7. J. Niu, J. Chen, D. Martens, X. Quan, F. Yang, A. Kettrup, K.-W. Schramm, Environ. Pollut. 123, 39 (2003)

8. T.S. Howe, S. Billings, R.J. Stolzberg, Environ. Sci. Technol. 38, 3294 (2004)

9. J.B. Korosi, G. Irvine, E.K. Skierszkan, J.R. Doyle, L.E. Kimpe, J. Janvier, J.M. Blais, Environ. Pollut. 182, 307 (2013)

10. H. Kylin, E. Grimvall, C. Oestman, Environ. Sci. Technol. 28, 1320 (1994).

11. J.J. Slaski, D.J. Archambault, X. Li, J.J. Slaski, Evaluation of Polycyclic Aromatic Hydrocarbon (PAH) Accumulation in Plants: The Potential Use of PAH Accumulation as a Marker of Exposure to Air Emissions from Oil and Gas Flares (Alberta Environment, Edmonton, 2000)

12. M. Howsam, K.C. Jones, P. Ineson, Environ. Pollut. 108, 413 (2000)

13. M. Howsam, K.C. Jones, P. Ineson, Chemosphere 44, 155 (2001)

14. F. De Nicola, G. Maisto, M.V. Prati, A. Alfani, Chemosphere 61, 432 (2005)

15. Official Journal of Laws No. 47 item 281 of 2008

16. Chief Inspectorate of Environmental Protection, Zanieczyszczenie powietrza wielopierścieniowymi węglowodorami aromatycznymi na stacjach tła miejskiego $w$ Polsce w 2013 r. (Warsaw, 2014).

17. Voivodship Inspectorate for Environmental Protection, Annual report (Katowice, 2014)

18. M.B. Yunker, R.W. Macdonald, L.R. Snowdon, B.R. Fowler, Org. Geochem. 33, 489 (2011)

19. M. Tobiszewski, J. Namieśnik, Environ. Pollut. 162, 110 (2012)

20. Y. Liu, S. Wang, R. Lohmann, N. Yu, C. Zhang, Y. Gao, J. Zhao, L. Ma, Atmos. Environ. 107, 129 (2015)

21. E. Stogiannidis, R. Laane, in:, D.M. Whitacre (Ed.), Rev. Environ. Contam. Toxicol., (Springer International Publishing, Cham, 2015)

22. S.Y.N. Yang, D.W. Connell, D.W. Hawker, S.I. Kayal, Sci. Total Environ. 102, 229 (1991)

23. H.-M. Hwang, T.L. Wade, J. Environ. Sci. Health Part A 43, 1243 (2008)

24. N. Ratola, A. Alves, E. Psillakis, Water. Air. Soil Pollut. 215, 189 (2011)

25. M. Mętrak, A. Ekonomiuk, B. Wiłkomirski, T. Staszewski, M. Suska-Malawska, Environ. Monit. Assess. 188, 456 (2016)

26. S. Orecchio, Atmos. Environ. 41, 8669 (2007)

27. M.B. Yunker, R.W. Macdonald, R. Vingarzan, R.H. Mitchell, D. Goyette, S. Sylvestre, Org. Geochem. 33, 489 (2002)

28. A. Dvorská , G. Lammel, J. Klánová, Atmos Environ 45, 420 (2011) 